\title{
Intercomparison between aerosol optical properties by a PREDE skyradiometer and CIMEL sunphotometer over Beijing, China
}

\author{
H. Che ${ }^{1}$, G. Shi ${ }^{2}$, A. Uchiyama ${ }^{3}$, A. Yamazaki ${ }^{3}$, H. Chen ${ }^{4}$, P. Goloub ${ }^{5}$, and X. Zhang ${ }^{1}$ \\ ${ }^{1}$ Key Laboratory of Atmospheric Chemistry (LAC), Centre for Atmosphere Watch and Services (CAWAS), \\ Chinese Academy of Meteorological Sciences (CAMS), CMA, Beijing, 100081, China \\ ${ }^{2}$ State Key Laboratory of Numerical Modeling for Atmospheric Sciences and Geophysical Fluid Dynamics \\ (LASG), Institute of Atmospheric Physics, Chinese Academy of Sciences, Beijing, 100029, China \\ ${ }^{3}$ Japan Meteorological Agency, Meteorological Research Institute, 1-1 Nagamine, Tsukuba, Ibaraki 305-0052, Japan \\ ${ }^{4}$ Laboratory for Middle Atmosphere and Global Environment Observation (LAGEO), Institute of Atmospheric Physics, \\ Chinese Academy of Sciences, Beijing, 100029, China \\ ${ }^{5}$ Laboratoire d'Optique Amosphérique, Université des Sciences et Technologies de Lille, 59655 Villeneuve d'Ascq, France
}

Received: 16 August 2007 - Published in Atmos. Chem. Phys. Discuss.: 14 November 2007

Revised: 7 May 2008 - Accepted: 18 May 2008 - Published: 25 June 2008

\begin{abstract}
This study compares the aerosol optical and physical properties simultaneously measured by a SKYNET PREDE skyradiometer and AERONET/PHOTONS CIMEL sunphotometer at a location in Beijing, China. Aerosol optical properties (AOP) including the Aerosol Optical Depth (AOD), Angstrom exponent $(\alpha)$, volume size distribution, single scattering albedo $(\omega)$ and the complex refractive index were compared. The difference between the two types of instruments was less than $1.3 \%$ for the AOD and less than $4 \%$ for the single scattering albedo below the wavelength of $670 \mathrm{~nm}$. There is a difference between the volume size distribution patterns derived from two instruments, which is probably due to difference of measurement protocols and inversion algorithms for the respective instruments.

AOP under three distinct weather conditions (background, haze, and dust days) over Beijing were compared by using the retrieved skyradiometer and sunphotometer data combined with MODIS satellite results, pyranometer measurements, $\mathrm{PM}_{10}$ measurements, and backtrajectory analysis. The results show that the significant difference of AOP under background, haze, and dust days over Beijing is probably due to different aerosol components under distinct weather conditions.
\end{abstract}

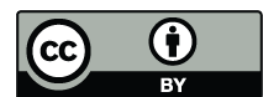

Correspondence to: G. Shi (shigy@mail.iap.ac.cn)

\section{Introduction}

Aerosol particles are very important in the studies of global and regional climate change (Ackerman, et al., 1981; Charlson et al., 1992) which can result in direct radiative forcing as well as indirect effects on clouds (e.g. droplet properties, cloud dynamics and lifetimes) (Hansen et al., 1997). It has been speculated that aerosol particles could contribute to the global and regional dimming (Stanhill et al., 2001; Che et al., 2005) and to the change of regional precipitation (Meanon et al., 2002). Despite many aerosol studies, the aerosol concentrations and optical properties are one of the largest sources of uncertainty in current assessments and predictions of global climatic change (IPCC, 2001; Hansen et al., 2000; Ramanathan et al., 2001).

Although ground-based measurement networks cannot obtain global coverage of aerosol optical characteristics like satellite measurements or aerosol models, they are very useful and accurate way to research aerosol optical properties. (Holben et al., 2001). The AERONET (Holben et al., 2001) and SKYNET (Nakajima et al., 2003) are the well known two ground-based aerosol-monitoring networks which use the CIMEL CE-318 sunphotometers and PREDE skyradiotometers, respectively (Holben et al., 1998; Uchiyama et al., 2005). These two networks have been used to measure the direct and diffuse solar radiation and to derive the aerosol

Published by Copernicus Publications on behalf of the European Geosciences Union. 
Table 1. Wavelengths for the two different instruments.

\begin{tabular}{lll}
\hline Wavelength & $\begin{array}{l}\text { PREDE POM-02 } \\
\text { skyradiometer }\end{array}$ & $\begin{array}{l}\text { CIMEL CE318 } \\
\text { sunphotometer }\end{array}$ \\
\hline Ch 1 & $315 \mathrm{~nm}$ & $440 \mathrm{~nm}$ \\
Ch 2 & $340 \mathrm{~nm}$ & $670 \mathrm{~nm}$ \\
Ch 3 & $380 \mathrm{~nm}$ & $870 \mathrm{~nm}$ \\
Ch 4 & $400 \mathrm{~nm}$ & $940 \mathrm{~nm}$ \\
Ch 5 & $500 \mathrm{~nm}$ & $1020 \mathrm{~nm}$ \\
Ch 6 & $670 \mathrm{~nm}$ & $870 \mathrm{~nm} \mathrm{P1}$ \\
Ch 7 & $870 \mathrm{~nm}$ & $870 \mathrm{~nm} \mathrm{P2}$ \\
Ch 8 & $940 \mathrm{~nm}$ & $870 \mathrm{~nm} \mathrm{P3}$ \\
Ch 9 & $1020 \mathrm{~nm}$ & \\
Ch 10 & $1225 \mathrm{~nm}$ & \\
Ch 11 & $2200 \mathrm{~nm}$ & \\
\hline
\end{tabular}

P1, P2, and P3 of CIMEL CE318 sunphotometer mean three polarization wavelengths

optical properties for the purpose of aerosol radiative forcing studies (Kim et al., 2004; Nakajima et al.,2003; Takemura et al., 2002; Dubovik et al., 2002; Eck et al., 2005; Holben et al., 2001; O'Neill et al., 2000; Smirnov et al., 2002).

Due to the difference in the measurement protocols and retrieval algorithms, it is very important to make sure that the aerosol optical properties are consistent with each other between these two networks. Though there were some intercomparison works between the results of CIMEL sunphotometer and PREDE skyradiometer, more details are needed to improve the retrieval algorithms and to verify the combination of the two networks. Sano et al. (2003) compared the AOD between CIMEL sunphotometer and PREDE skyradiometer measurements. It was found that the difference of AOD at $670 \mathrm{~nm}$ between the two instruments is less than $4 \%$ based on one day observation. Because the aerosol optical properties were retrieved by SKYRAD.PACK (the software package for analyses of sky radiometer data to obtain aerosol optical properties) version, there was large discrepancy between two instruments. Sano et al. (2003) also pointed out that simultaneous observations for two instruments should be continued at least during one year for verifying the combined use of the two networks.

Campanelli et al. (2004) also compared the aerosol optical properties between CIMEL sunphotometer and PREDE skyradiometer measurements based on about two weeks observations. They found the AOD of two instruments are comparable between $10-12 \%$, for optical depth reference values of $\sim 0.12$ at $500 \mathrm{~nm}$. The Angstrom exponent is also comparable within $10-12 \%$. The SSA retrieved by SKYRAD.PACK version 4.0 is found to be within $10-12 \%$, comparing with Dubovik spherical retrievals. The retrieved refractive index results did not agree very well because of the few number of common measurements and the unstable SKYRAD.PACK version 4.0 algorithm.
Table 2. Averaged single scattering albedo, refractive index, and their absolute and percentage differences between skyradiometer and sunphotometer at all wavelengths for all simultaneous data.

\begin{tabular}{lrrrrr}
\hline & $440 / 400 \mathrm{~nm}$ & $440 / 500 \mathrm{~nm}$ & $670 \mathrm{~nm}$ & $870 \mathrm{~nm}$ & $1020 \mathrm{~nm}$ \\
\hline$\omega_{a}$ & 0.88 & 0.88 & 0.89 & 0.87 & 0.86 \\
$\omega_{s}$ & 0.89 & 0.90 & 0.93 & 0.94 & 0.93 \\
$\mathrm{~m}_{r a}$ & 1.48 & 1.48 & 1.50 & 1.51 & 1.52 \\
$\mathrm{~m}_{r s}$ & 1.51 & 1.51 & 1.50 & 1.51 & 1.49 \\
$\mathrm{~m}_{i a}$ & 0.017 & 0.017 & 0.011 & 0.012 & 0.013 \\
$\mathrm{~m}_{i s}$ & 0.014 & 0.011 & 0.006 & 0.004 & 0.005 \\
$\delta \omega$ & -0.01 & -0.03 & -0.03 & -0.06 & -0.07 \\
$\delta \mathrm{m}_{r}$ & -0.04 & -0.04 & 0.00 & 0.01 & 0.02 \\
$\delta \mathrm{m}_{i}$ & 0.003 & 0.006 & 0.004 & 0.008 & 0.008 \\
$\delta \omega \%$ & -1.31 & -3.10 & -3.40 & -7.33 & -7.57 \\
$\delta \mathrm{m}_{r} \%$ & -2.56 & -2.46 & 0.23 & 0.36 & 1.43 \\
$\mathrm{R}_{m i}$ & 1.21 & 1.55 & 1.83 & 3.00 & 2.60 \\
\hline & & & & &
\end{tabular}

$\omega, \mathrm{m}_{r}$ and $\mathrm{m}_{i}$ mean averaged single scattering albedo, real part of refractive index and the imaginary part of refractive index; subscript $\mathrm{a}$ and $\mathrm{s}$ means AERONET sunphotometer and SKYNET skyradiometer; $\delta$ - and $\delta-\%$ mean absolute and percentage difference between skyradiometer and sunphotometer, respectively. $\mathrm{R}_{m i}$ means the ratio of AERONET $\mathrm{m}_{i}$ to SKYNET $\mathrm{m}_{i}$.

The aim of this work is to compare nearly one year simultaneous observations of AERONET/PHOTONS and SKYNET stations in Beijing. Since the aerosol characteristics over Beijing are very representative for the research of aerosol optical properties due to heavy anthropogenic aerosol loading throughout the year and frequent dust storm events during the spring season, the comparison will shed some light on the consistency and discrepancy of the two measurement methods and contribute to the combination of the aerosol optical properties between AERONET and SKYNET on a larger scale. This will eventually fill the gap that AERONET has in Asia.

\section{Instrumentations, protocols, calibration and re- trievals}

\subsection{Instrumentation and protocols}

A PREDE POM-02 skyradiometer (SKYNET) and a CIMEL CE-318 sunphotometer (AERONET/PHOTONS) have been installed in September 2003 and March 2001, respectively at Institute of Atmospheric Physics $\left(116.38^{\circ} \mathrm{E}, 39.97^{\circ} \mathrm{N}\right.$, $92.0 \mathrm{~m}$ ) in Beijing, China to measure the aerosol optical properties. They have been continuously running since then. The CIMEL sunphotometer makes the direct spectral solar irradiance and sky radiance for solar almucantar scenario or principal plane scenario measurements within a $1.2^{\circ}$ full field-of-view at five normal bands at 440, 670, 870, 940, and $1020 \mathrm{~nm}$ and three polarization bands at $870 \mathrm{~nm}$ (Holben et al., 1998). The PREDE sky-radiometer measures the 

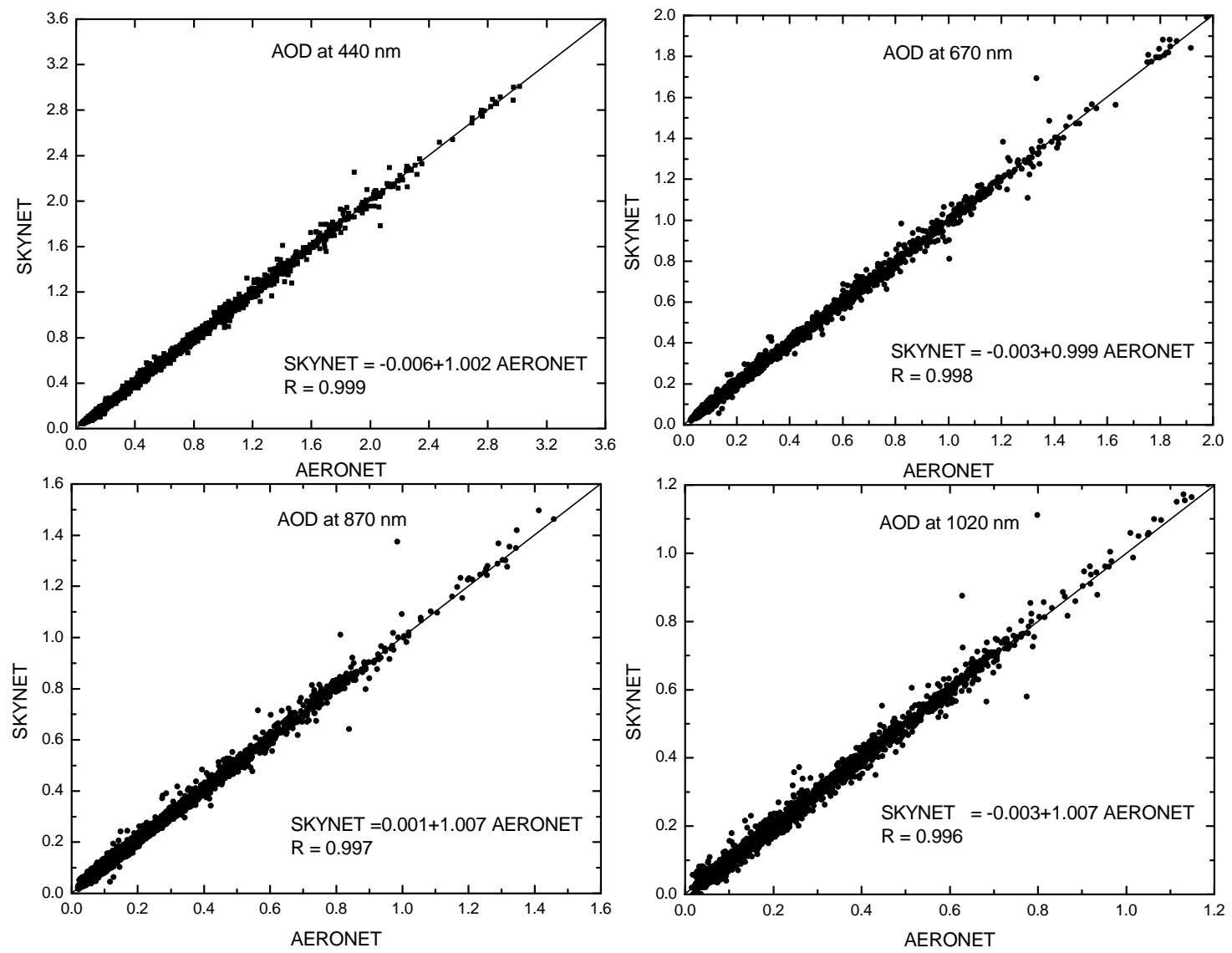

Fig. 1. Scattergrams of aerosol optical depth between PREDE skyradiometer and CIMEL sunphotometer data at wavelengths of 440,670 , 870 and $1020 \mathrm{~nm}$ over Beijing.

solar direct irradiance and the radiance from the sky within a $1.0^{\circ}$ full field-of-view at eleven bands of $315,340,380,400$, $500,670,870,940,1225,1600$, and $2200 \mathrm{~nm}$ at every 10 or 15 min (Uchiyama et al., 2005). Wavelengths for the two different instruments are shown in Table 1 . The sky radiance is measured at 24 pre-defined scattering angles at regular time intervals. In this study, data from five channels at 400, 500, 670,870 , and $1020 \mathrm{~nm}$ were used to retrieve AOP over Beijing.

A set of Kipp \& Zonen CM21 pyranometer was also set up to measure the global solar irradiance (305 to $2800 \mathrm{~nm}$ spectral range) every $10 \mathrm{~s}$ automatically at Institute of Atmospheric Physics in September 2003, which is a high precision pyranometer with strictly selected domes. Because of the high optical quality of these domes, the directional error is reduced to less than $10 \mathrm{~W} / \mathrm{m}^{2}$.

Additionally, a TEOM Series 1400a Ambient Particulate Monitor was installed at Beijing Observatory $\left(116.47^{\circ} \mathrm{E}\right.$, $39.60^{\circ} \mathrm{N}, 31.3 \mathrm{~m}$ ) of China Meteorological Administration (CMA) to monitor the Particle Matter (PM) mass concentration in January 2004. The instrument measured the $\mathrm{PM}_{10}$ mass concentrations every $5 \mathrm{~min}$ automatically. The mass transducer minimum detection limit is $0.01 \mu \mathrm{g}$. The precision for $10-\mathrm{min}$ and $1-\mathrm{h}$ averaged data is $5.0 \mu \mathrm{g} / \mathrm{m}^{3}$ and $1.5 \mu \mathrm{g} / \mathrm{m}^{3}$, respectively.

\subsection{Calibration}

The CIMEL sunphotometer located at Beijing is calibrated using PHOTONS (http://www-loa.univ-lille1.fr/photons/) calibration facilities in Lille (LOA/USTL, France), Carpentras (Meteofrance) and Izana Observatory (INM, Spain) following the calibration protocol used by NASA staff. Accuracy on AOD is better or around 0.01 and radiance is better than $4-5 \%$ with the standard laboratory integrating sphere (Holben et al., 1998; Eck et al., 1999).

The calibration of the PREDE skyradiometer was similar to that of CIMEL sunphotometer. It was calibrated for the sky radiance using an integrating sphere at Tsukuba Space Center and for the direct solar irradiance using the Langley plot method at Mauna Loa Observatory (MLO), Hawaii Island. The precision of the in situ method has been estimated to be within 1-2.5\%, depending on the wavelength (Campanelli, 2004b). 

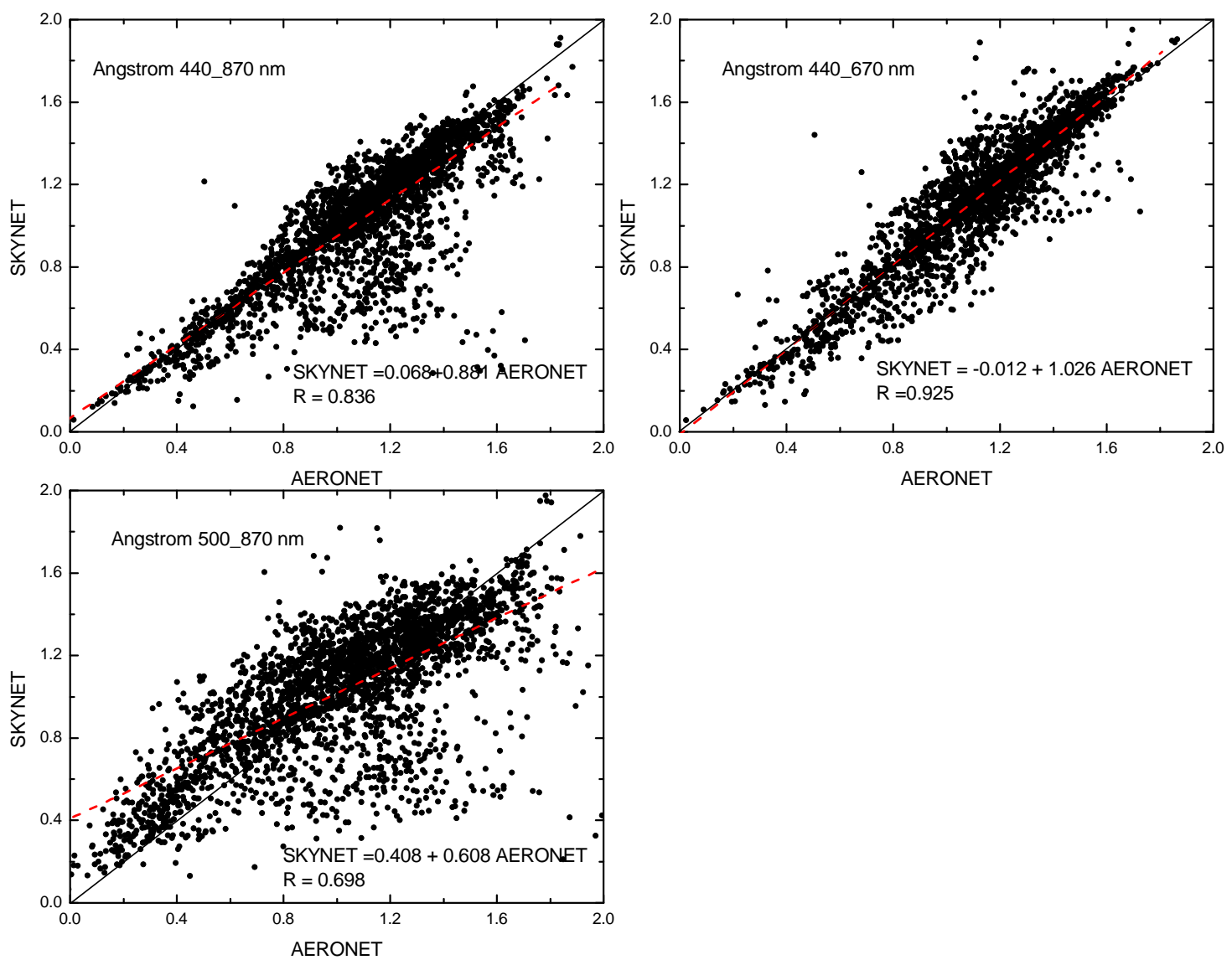

Fig. 2. Scattergrams of Angstrom exponent at 440-870 nm, 440-670 nm, and 500-870 nm between PREDE skyradiometer and CIMEL sunphotometer data over Beijing. The red dotted line means the fitted linear regression curve.

\subsection{Retrieval methods}

Aerosol optical properties of PREDE skyradiometer were retrieved by using SKYRAD.PACK 4.2 (the latest version), which is a software to analyze the PREDE skyradiometer data and the sky radiance developed by Nakajima et al. (1996) and Dubovik and King (2000b). The aerosol optical depth, size distribution, single-scattering albedo, and complex refractive index were derived by using a radiative transfer code as well as linear and nonlinear inversion scheme (Nakajima et al., 1996). The retrieved aerosol optical depth, $\tau_{a(\lambda)}$, is defined as:

$\tau_{a}(\lambda)=\int_{r_{m}}^{r_{M}} \pi r^{2} \mathrm{Q}_{\mathrm{ext}}(x, m) n(r) d r$

where $\mathrm{Q}_{\mathrm{ext}}$ is the efficiency factor for extinction as given by Mie theory for spherical particles, $x=(2 \pi / \lambda) \mathrm{r}$ is size parameter, $\mathrm{n}(\mathrm{r})$ is columnar radius distribution of aerosol, $\mathrm{r}_{m}$ and $\mathrm{r}_{M}$ are minimum and maximum aerosol radii, respectively. $\mathrm{m}=\mathrm{m}_{r}-\mathrm{im}_{i}$ is aerosol complex refractive index which is derived by an inversion method similar to that of Dubovik et al. (2000). The directly measured AOD is calculated from the direct solar irradiance measurement at each wavelength by using the Beer-Lambert-Bouguer law.

Similar to the PREDE skyradiometer, direct solar irradiance measurements of CIMEL sunphotometer at 440, 670, 870 , and $1020 \mathrm{~nm}$ are used to calculate aerosol optical depth (Dubovik et al., 2000a). At the same time, aerosol optical depth, size distribution, refractive index and single scattering albedo $(\omega)$ are also retrieved by using the sky radiance almucantar measurements and the direct sun measurements through a combined spherical and spheroid particle model (Dubovik et al., 2000b; 2006). The volume particle size distribution is retrieved in 22 logarithmically equidistant bins in the range of sizes $0.05 \mu \mathrm{m} \leq \mathrm{r} \leq 15 \mu \mathrm{m}$. The columnar volume spectrum is defined as:

$$
\frac{d V}{d \ln r}=\frac{V_{0}}{\sigma \sqrt{2 \pi}} \exp \left[-\frac{\left(\ln \left(r / r_{m}\right)\right)^{2}}{2 \sigma^{2}}\right]
$$

where $\mathrm{dV} / \mathrm{dln}\left(\mu \mathrm{m}^{3} / \mu \mathrm{m}^{2}\right)$ is the volume distribution, $\mathrm{V}_{0}$ is the volume concentration, and $\mathrm{r}, \mathrm{r}_{m} \sigma$ denote radius, volume median radius, and standard deviation of the particles, respectively (Dubovik et al., 2002; Kim et al., 2004). The real 

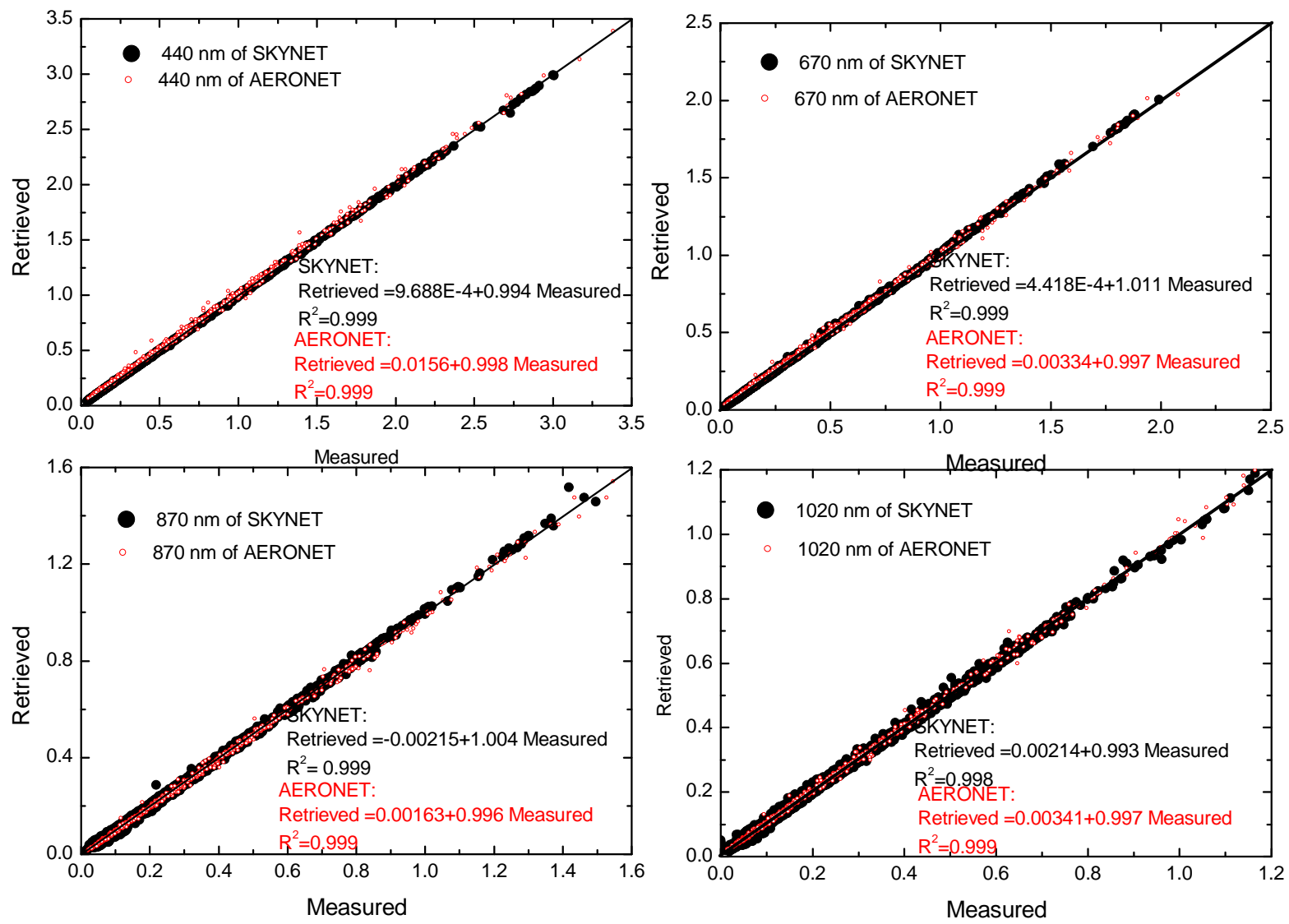

Fig. 3. Scattergrams of aerosol optical depth between the retrieved and measured results of PREDE skyradiometer and CIMEL sunphotometer over Beijing.

and imaginary parts of the complex refractive index retrieved for the wavelengths corresponding to sky radiance measurements are assumed in the ranges of $1.33-1.6$ and $0.0005-0.5$, respectively.

Since the two radiometers are equipped with only three common wavelengths $(670,870$, and $1020 \mathrm{~nm})$, the optical depth at $440 \mathrm{~nm}$ wavelengths for PREDE skyradiometer was calculated by using Eq. (a) and Eq. (b):

$$
\begin{aligned}
& \alpha=\frac{\log _{10}\left(\frac{\tau_{400}}{\tau_{500}}\right)}{\log _{10}\left(\frac{500}{400}\right)}(\mathrm{a}) \\
& \tau_{440}=\tau_{400} \cdot\left(\frac{440}{400}\right)^{-\alpha}(\mathrm{b})
\end{aligned}
$$

Where $\alpha$ means the wavelength exponent; and $\tau_{400}, \tau_{500}, \tau_{440}$ mean the AOD at $400 \mathrm{~nm}, 500 \mathrm{~nm}$, and $440 \mathrm{~nm}$, respectively.

The results between two instruments were compared by using the measurement data less than 3-min apart to keep relatively simultaneous observation.

\section{Results and discussions}

\subsection{Intercomparison of AOP}

The raw data retrieved by SKYRAD.PACK 4.2 from the SKYNET PREDE skyradiometer were used to compare the level 2.0 data retrieved by the version 2 direct sun algorithm from the AERONET/PHOTONS CIMEL sunphotometer measurements which were considered as cloud-screened and high-quality data (Smirnov et al., 2000).

The intercomparisons of AOD and Angstrom exponent between the PREDE skyradiometer and CIMEL sunphotometer were based on the 3169 measurements taken within 3min from each other for the 220 days. Figure 1 shows the plots of AOD values at each wavelength derived from the solar direct irradiance between the two instruments. High correlation was found with a significant coefficient larger than 0.995 at each band. The difference (defined as $\frac{\left.\text { mean }_{\text {SKYNET }}-\text { mean }_{A E R O N E T} \%\right)}{\text { mean }_{A E R O N E T}}$ ) between the two instruments at $1020 \mathrm{~nm}, 870 \mathrm{~nm}, 670 \mathrm{~nm}$, and $440 \mathrm{~nm}$, is less than $0.82 \%$, $1.27 \%, 1.03 \%$, and $0.91 \%$, respectively. This confirms the high consistency of AOD for the CIMEL sunphotometer and PREDE skyradiometer measurement results. 

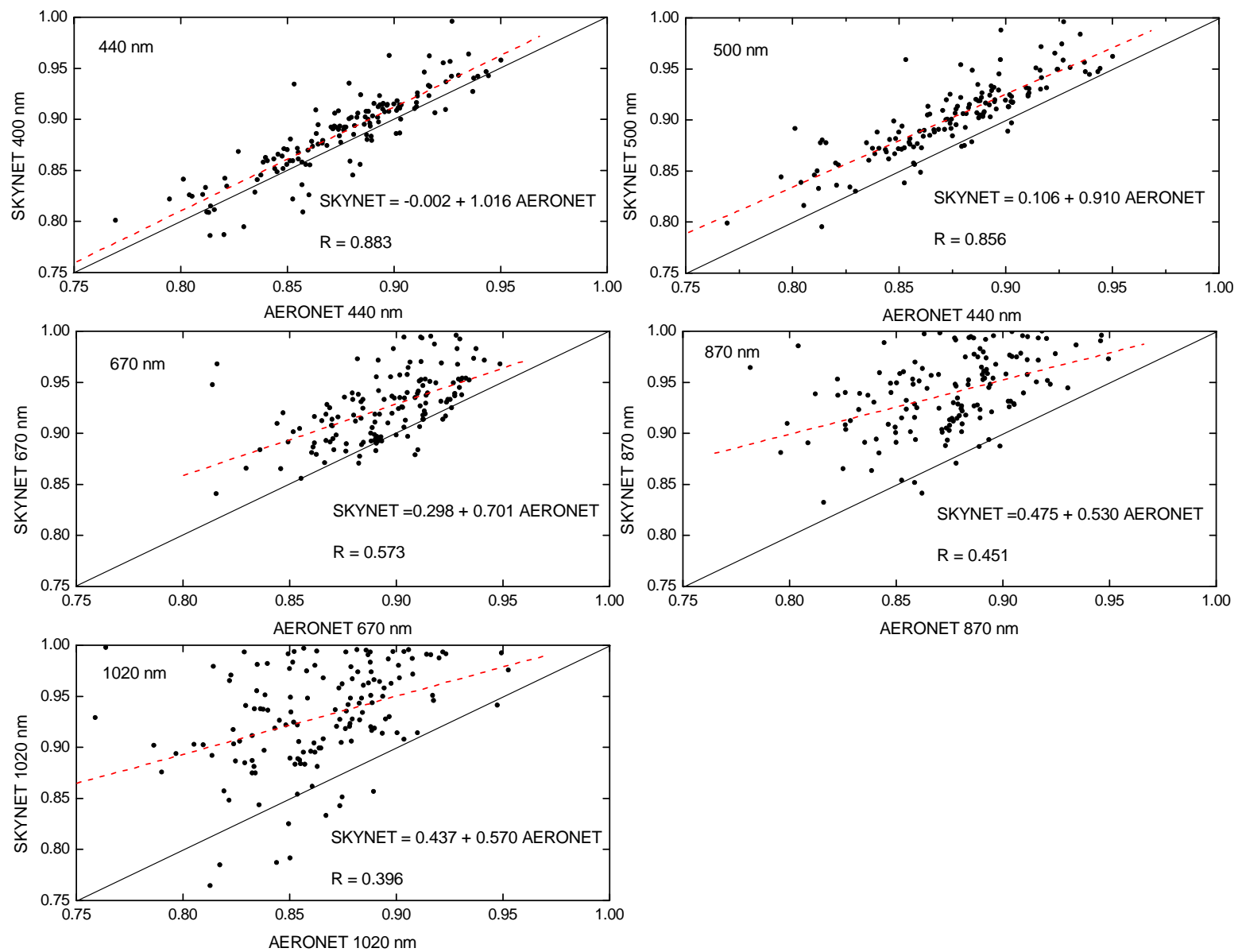

Fig. 4. Scattergrams of single scattering albedo between PREDE skyradiometer and CIMEL sunphotometer data at wavelengths of 400, 500, 670,870 and $1020 \mathrm{~nm}$ over Beijing. Only data with $\mathrm{AOD}>0.4$ are shown. The red dotted line means the fitted linear regression curve.

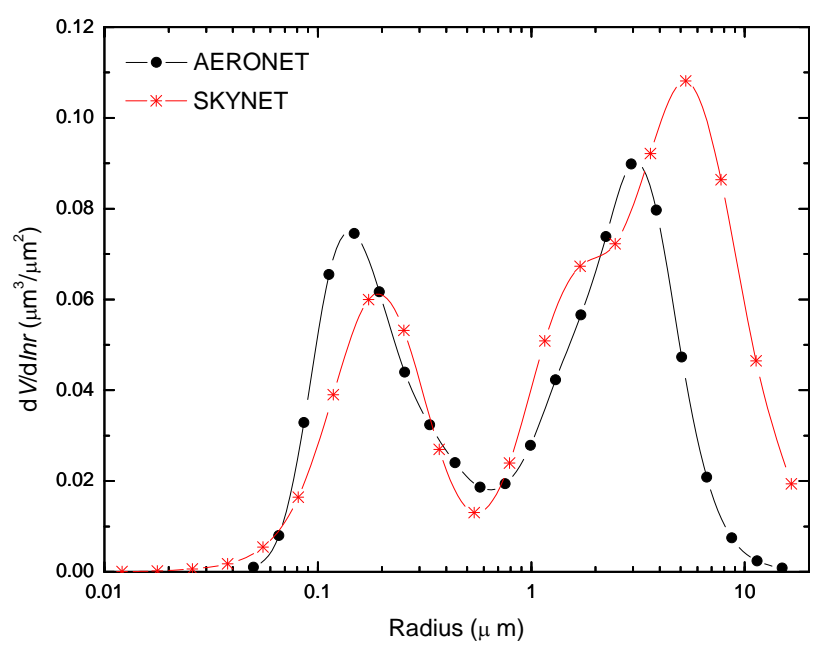

Fig. 5. Retrieved volume size distribution of PREDE skyradiometer and CIMEL sunphotometer over Beijing.
There are significant linear correlations of Angstrom wavelength exponents computed from instantaneous measurements between the two instruments (Fig. 2). The correlation coefficient of Angstrom exponents from $440 \mathrm{~nm}$ to $870 \mathrm{~nm}\left(\alpha_{440 \_870}\right)$ between two instruments is 0.84 . And it is about 0.93 and 0.70 for $\alpha_{440 \_670}$ and $\alpha_{500 \_870}$, respectively. The linear regression equations of $\alpha_{440 \_870}, \alpha_{440 \_670}$, and $\alpha_{500 \_870}$ between the two instruments are shown in Fig. 2. The slope of $\alpha_{500 \_870}$ is only about 0.608 , which is lower than those of $\alpha_{440 \_870}$ and $\alpha_{440 \_670}$. The whole averaged $\alpha_{440 \_870}$, $\alpha_{440 \_670}$ and $\alpha_{500 \_870}$ based on all 3169 pairs of data between two instruments differ about $5.73 \%, 1.56 \%$, and $0.06 \%$, respectively. This could be caused by the lack of direct measurements at $500 \mathrm{~nm}$ for CIMEL sunphotometer. The AOD at $500 \mathrm{~nm}$ has to be derived from other wavelengths measurements. The difference of $\alpha_{500 \_870}$ between the two instruments seems extremely small for values that correlate so poor (as seen in Fig. 2), especially since the percentages calculated for larger wavelengths are larger despite the better correlation. 

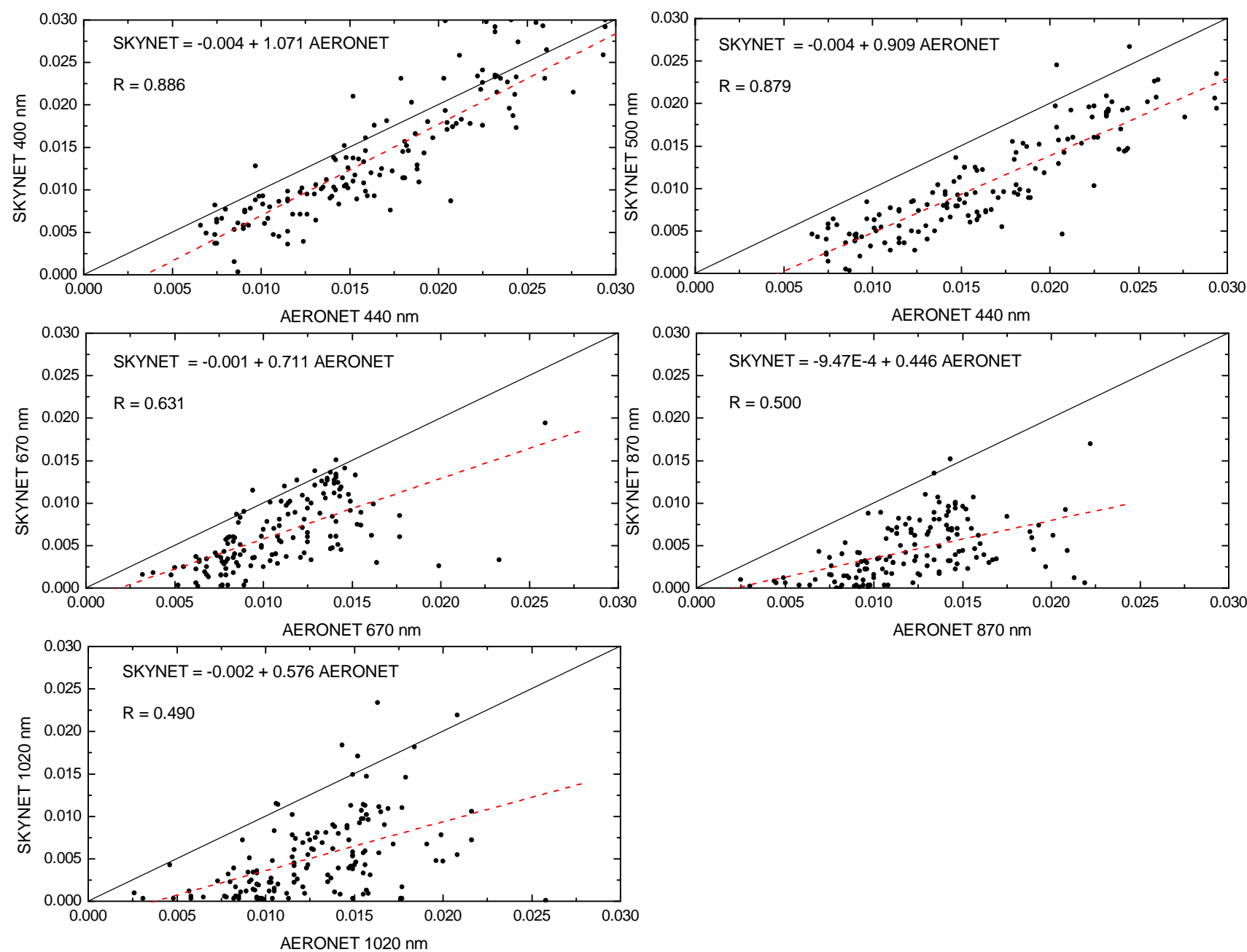

AERONET $870 \mathrm{~nm}$

Fig. 6. Scattergrams of imaginary part of refractive index between PREDE skyradiometer and CIMEL sunphotometer data at wavelengths of 400, 500, 670, 870 and $1020 \mathrm{~nm}$ over Beijing. Only data with AOD>0.4 are shown. The red dotted line means the fitted linear regression curve.

Figure 3 shows the directly measured AOD results and the retrieval ones for PREDE skyradiometer and CIMEL sunphotometer at 1020, 870, 670, and $440 \mathrm{~nm}$, respectively. For both instruments, there are highly significant linear relationships with correlation coefficient larger than 0.99 between the measured and retrieved values for all of four wavelengths. The difference between the measured and retrieved values of PREDE skyradiometer is about $0.35 \%, 0.42 \%, 1.23 \%$ and $0.40 \%$ for $1020,870,670$, and $440 \mathrm{~nm}$, respectively. And the difference between the measured and retrieved values of PREDE skyradiometer is about $0.86 \%, 0.04 \%, 0.37 \%$ and $1.89 \%$ for $1020,870,670$, and $440 \mathrm{~nm}$, respectively.

From the above analysis, it is seen that there is very small difference of AOD $(<1.3 \%)$ and Angstrom exponent $(<5.8 \%)$ for all wavelengths between PREDE skyradiometer measurements and CIMEL sunphotometer measurements. The difference between PREDE skyradiometer measured and retrieved values of AOD and Angstrom exponent at all wavelengths is also very small $(<1.3 \%$ for AOD and $<4.1 \%$ for $\alpha$ ).

Because the daily measurements of sky radiance by CIMEL sunphotometer were less frequent than those by PREDE skyradiometer, it was found that only 142 simultaneous measurements over 69 days during all measurement period could be used to compare the single scattering albedo and the complex refractive index between two instruments. Single scattering albedo $(\omega)$ results retrieved from the PREDE skyradiometer and the CIMEL sunphotometer were compared in Fig. 4. The mean values of $\omega$ retrieved from the PREDE skyradiometer are about 0.01 (1.31\%), 0.03 (3.10\%), 0.03 (3.40\%), 0.06 (7.33\%), and 0.07 $(7.57 \%)$ larger than those from the CIMEL sunphotometer at $440,500,670,870$, and $1020 \mathrm{~nm}$, respectively. $\omega_{s 400}$ and $\omega_{s 500}$ by the PREDE skyradiometer correlate to the $\omega_{a 440}$ 


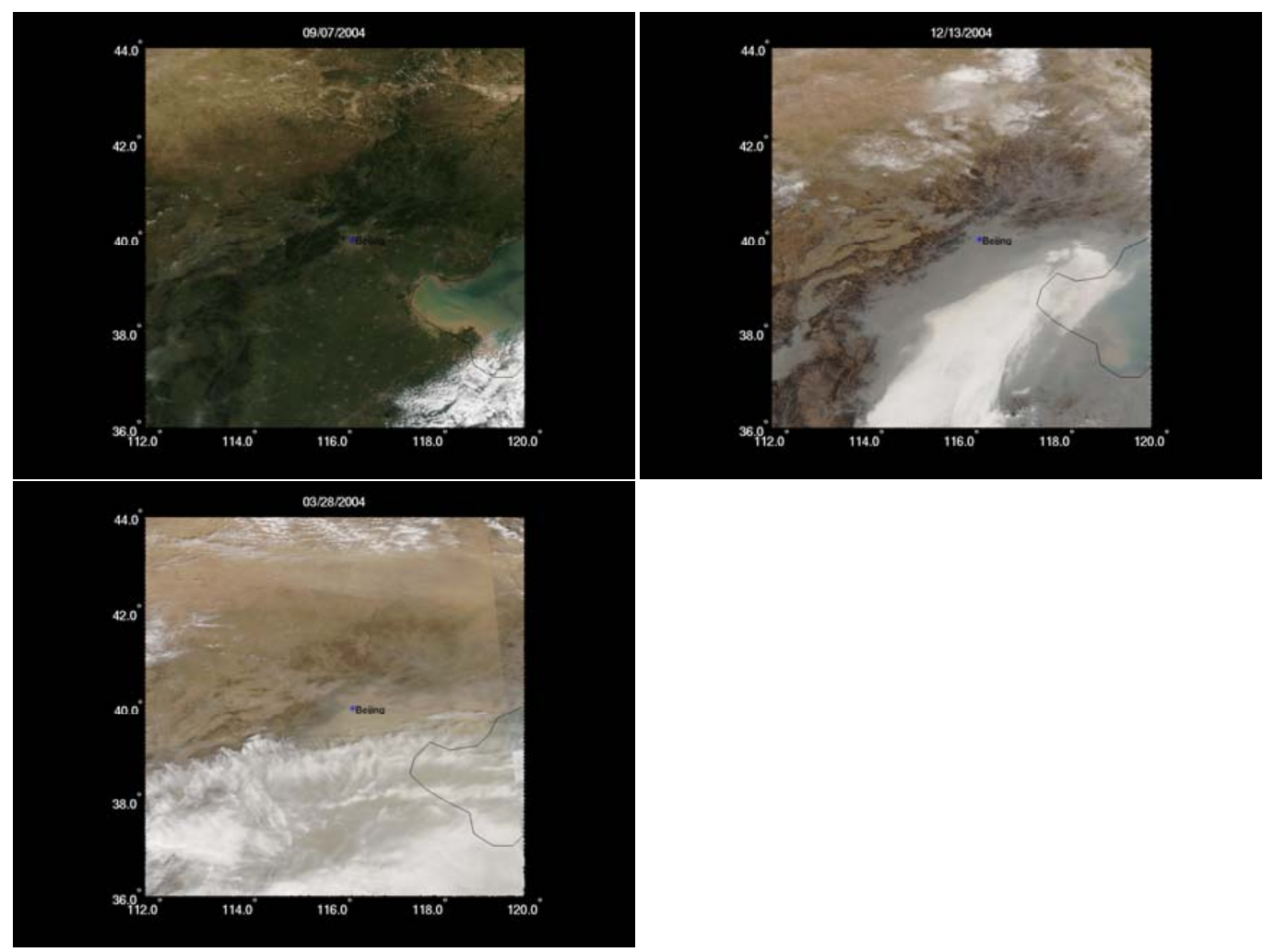

Fig. 7. AQUA-MODIS images under clean (top-left), haze (top-right) and dust (bottom-left) weather conditions over Beijing on 7 September, 13 December, and 28 March in 2004. Their overpass time is 04:55, 05:35 and 04:20 UTC, respectively.
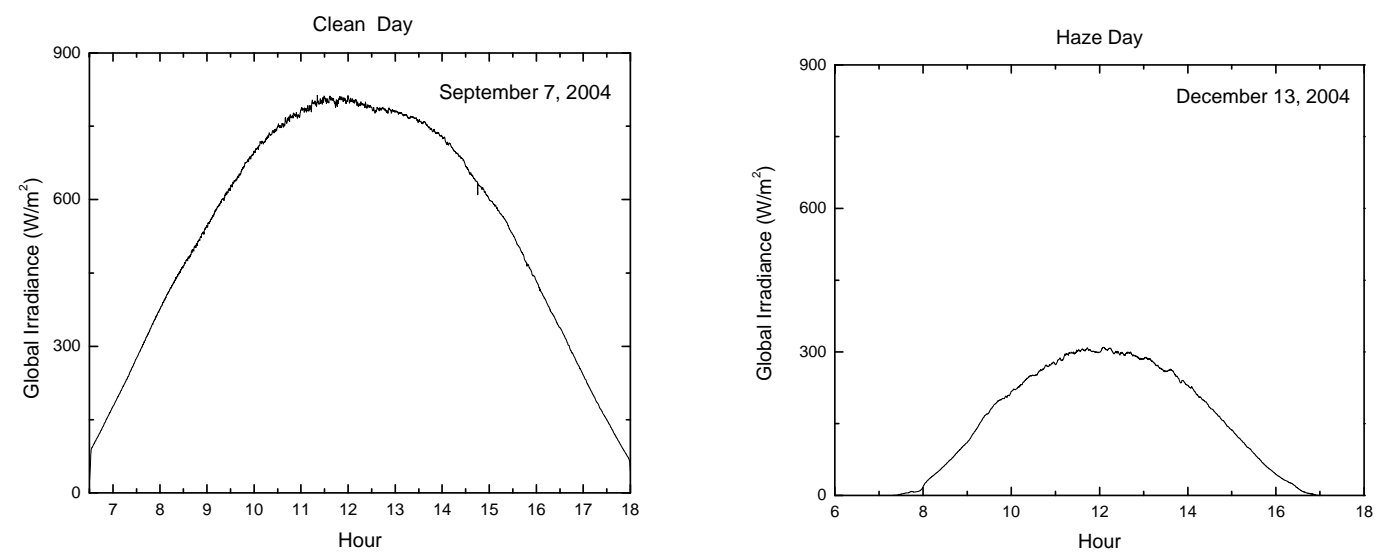

Fig. 8. 10-s averages of global solar irradiance of Kipp \& Zonen CM21 pyranometer measurement under clean (left) and haze (right) weather conditions over Beijing on 7 September, 13 December in 2004.

by the CIMEL sunphotometer with $R=0.88$ and 0.86 , respectively. Although the statistical analysis shows there are also obvious linear relationships (within the $99 \%$ confidence level) between the results from the PREDE skyradiometer and CIMEL sunphotometer at 670,870 , and $1020 \mathrm{~nm}$, their patterns are rather scattered with a correlation coefficients around $0.57,0.45$, and 0.40 , respectively.
Intercomparison of the volume size distribution was carried out based on the 193 simultaneous measurements over 95 days during the whole measurement period. The volumes at each bin are averaged all together for PREDE skyradiometer and CIMEL sunphotometer, respectively (Fig. 5). Generally, there is a difference between the PREDE skyradiometer and CIMEL sunphotometer results. One can see 

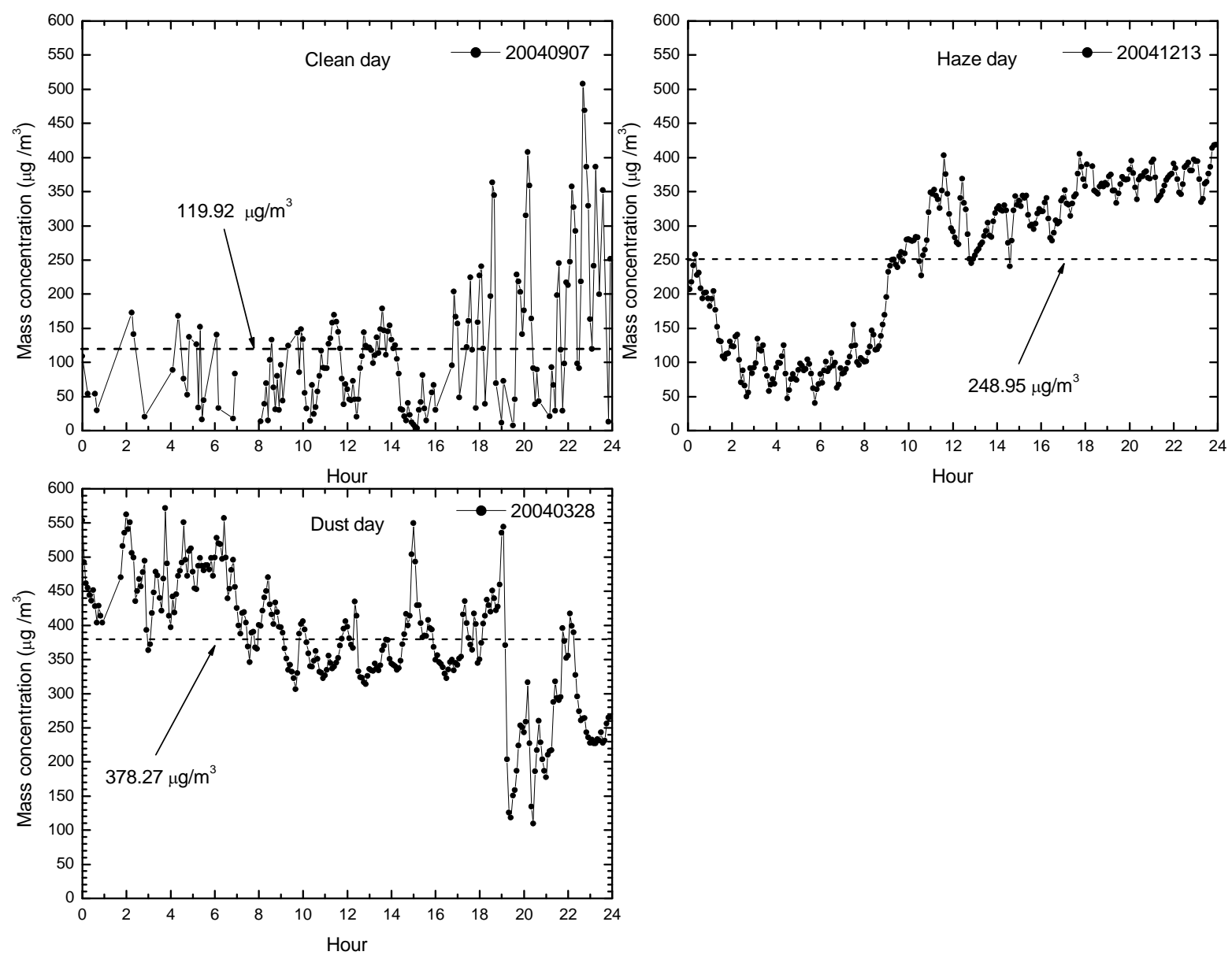

Fig. 9. Five-minute averages of $\mathrm{PM}_{10}$ concentration under clean (top-left), haze (top-right) and dust (bottom-left) weather conditions over Beijing on 7 September, 13 December, and 28 March in 2004.

that the size distribution from the CIMEL sunphotometer shows a bi-modal pattern with two peak volumes at radius of $0.15 \mu \mathrm{m}$ and $2.94 \mu \mathrm{m}$ with the volume size spectra $(\mathrm{dV} / \mathrm{dlnr})$ of 0.07 and $0.09 \mu \mathrm{m}^{3} / \mu \mathrm{m}^{2}$, while the PREDE skyradiometer shows a tri-modal pattern with three peak volume at radius of $0.17 \mu \mathrm{m}, 1.69 \mu \mathrm{m}$ and $5.29 \mu \mathrm{m}$ with $\mathrm{dV} / \mathrm{dln}$ of $0.06,0.07$ and $0.11 \mu \mathrm{m}^{3} / \mu \mathrm{m}^{2}$, respectively. The difference between two patterns of the volume size distributions is probably due to the different retrieval algorithms. The assumptions of the size distribution between SKYNET and AERONET algorithms are different. The AERONET algorithm uses 22 stage radii $(0.05,0.07,0.09,0.11,0.15,0.19,0.26,0.33,0.44$, $0.58,0.76,0.99,1.30,1.71,2.24,2.94,3.86,5.06,6.64,8.71$, 11.43 , and $15.00 \mu \mathrm{m})$ to retrieve the volume size distribution, while SKYNET algorithm uses 20 stage radii $(0.01,0.02$, $0.03,0.04,0.06,0.08,0.12,0.17,0.25,0.37,0.54,0.79,1.16$, $1.69,2.47,3.62,5.29,7.73,11.31$, and $16.54 \mu \mathrm{m})$. From Fig. 5 one can see that the volume size spectra $(\mathrm{dV} / \mathrm{dln} r)$ is nearly $0 \mu \mathrm{m}^{3} / \mu \mathrm{m}^{2}$ for the radii less than $0.05 \mu \mathrm{m}$ and larger than $15.00 \mu \mathrm{m}$ for most cases of AERONET results.
However, in SKYNET retrieve results, the volume size spectra $(\mathrm{dV} / \mathrm{dln}$ ) is NOT 0 for the radii less than $0.05 \mu \mathrm{m}$ and larger than $15.00 \mu \mathrm{m}$ for most cases. The volume size distribution from CIMEL sunphotometer measurements was retrieved by combined spherical and spheroid particle model almucantar retrievals (Dubovik, 2000b). However, there is no spheroid particle model included in SKYRAD.PACK 4.2. Another possible reason is due to the data used from different channels. For the CIMEL sunphotometer, four spectral channels of 440,670, 870 and $1020 \mathrm{~nm}$ were used, while for the PREDE skyradiometer, five spectral channels of 400, 500, 670, 870 and $1020 \mathrm{~nm}$ were used.

On the contrary to the single scattering albedo, the results of imaginary part of complex refractive index $\left(\mathrm{m}_{i}\right)$ retrieved from PREDE skyradiometer at all wavelengths are systematically lower than those by the CIMEL sunphotometer (Fig. 6). The mean values of $\mathrm{m}_{i}$ retrieved from the PREDE skyradiometer are about 0.003, 0.006, 0.004, 0.008, and 0.008 lower than those from the CIMEL sunphotometer for $\mathrm{m}_{i s 400}$ with $\mathrm{m}_{i a 440}, \mathrm{~m}_{i s 400}$ with $\mathrm{m}_{i a 500}, \mathrm{~m}_{i s 670}$ with $\mathrm{m}_{i a 670}, \mathrm{~m}_{i s 870}$ 

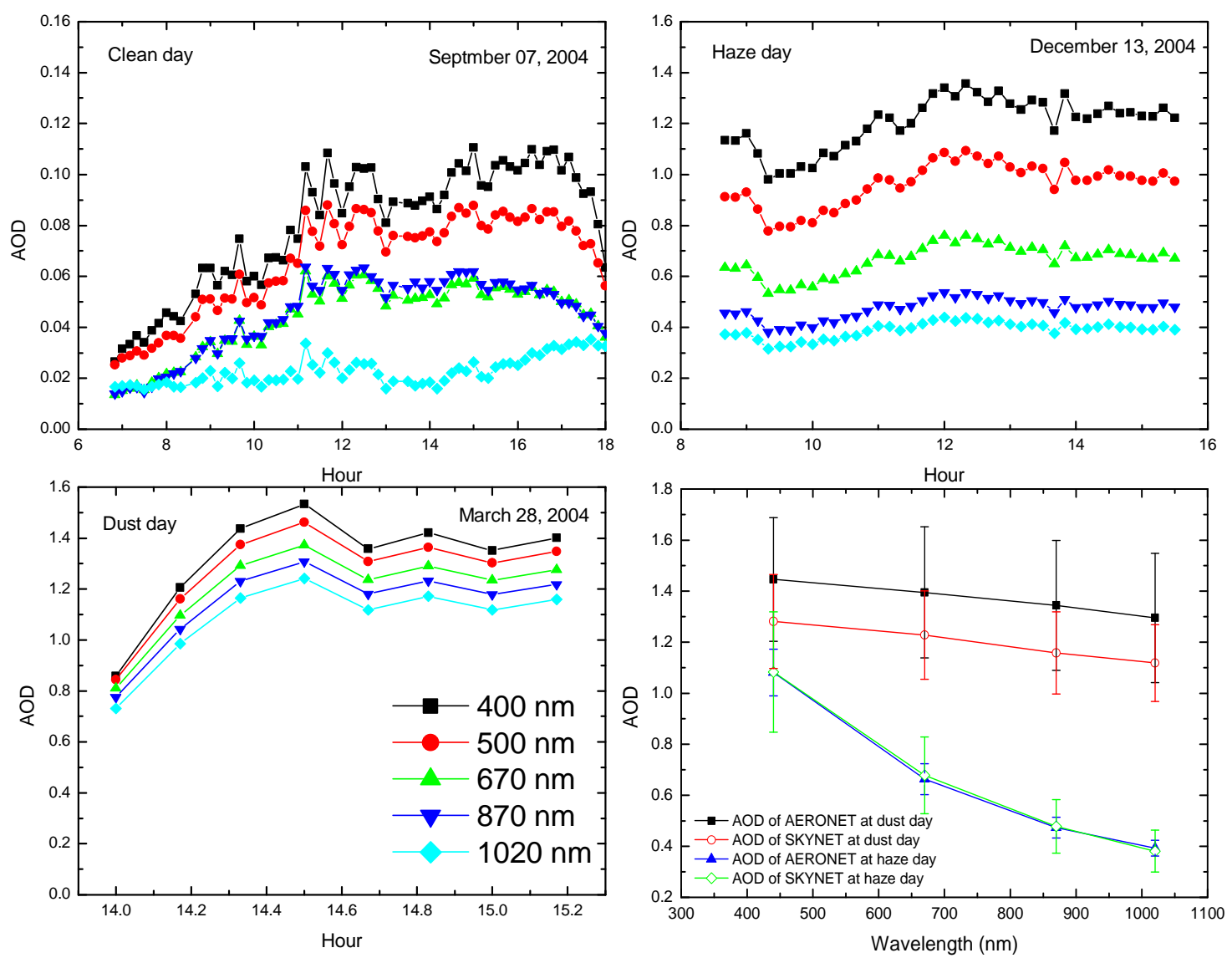

Fig. 10. AOD at 400, 500, 670, 870, and $1020 \mathrm{~nm}$ from directly-measured PREDE skyradiometer data under clean (top-left), haze (top-right) and dust (bottom-left) weather conditions over Beijing on 7 September, 13 December, and 28 March in 2004 and the daily averaged AOD at 440, 670, 870, and $1020 \mathrm{~nm}$ from retrieved PREDE skyradiometer and directly-measured CIMEL sunphotometer data under haze and dust weather conditions (bottom-right).

with $\mathrm{m}_{i a 870}$, and $\mathrm{m}_{i s 1020}$ with $\mathrm{m}_{i a 1020}$, which means the AERONET results are about $1.21,1.55,1.83,3.00$ and 2.60 times as large as those SKYNET ones, respectively. The $\mathrm{m}_{i s}$ and $\mathrm{m}_{i a}$ mean the imaginary part of refractive index of SKYNET and AERONET, respectively. $\mathrm{m}_{i s 400}$ and $\mathrm{m}_{i s 500}$ by the PREDE skyradiometer are linearly correlated with $\mathrm{m}_{i a 440}$ by the CIMEL sunphotometer with $R=0.89$ and 0.88 , respectively. Although the statistical results show there are also obvious linear correlations between PREDE skyradiometer and CIMEL sunphotometer at 670,870 , and $1020 \mathrm{~nm}$, their correlations are also very scattered with correlation coefficients around $0.63,0.50$, and 0.49 , respectively.

Generally, the difference in $\mathrm{m}_{r}$ between the two instruments is less than that in $\mathrm{m}_{i}$ (Table 2). The results for the real part of complex refractive index $\left(\mathrm{m}_{r}\right)$ show that $\mathrm{m}_{r}$ at wavelengths of 400 and $500 \mathrm{~nm}$ by the PREDE skyradiometer are lower than that at $440 \mathrm{~nm}$ by the CIMEL sunphotometer but larger than that at 670,870 , and $1020 \mathrm{~nm}$ by the CIMEL sunphotometer. The mean values of $\mathrm{m}_{r}$ retrieved from the PREDE skyradiometer are about 0.038
(2.56\%), $0.036(2.46 \%)$ lower for $\mathrm{m}_{r s 400}$ with $\mathrm{m}_{r a 440}, \mathrm{~m}_{r s 400}$ with $\mathrm{m}_{\text {ras }}$ but $0.003(0.23 \%), 0.005(0.36 \%)$, and 0.022 $(1.43 \%)$ larger for $\mathrm{m}_{r s 670}$ with $\mathrm{m}_{r a 670}, \mathrm{~m}_{r s 870}$ with $\mathrm{m}_{r a 870}$, and $\mathrm{m}_{r s 1020}$ with $\mathrm{m}_{r a 1020}$ than those from the CIMEL sunphotometer. The $\mathrm{m}_{r s}$ and $\mathrm{m}_{r a}$ mean the real part of refractive index of SKYNET and AERONET, respectively.

The above intercomparisons show the consistency of the AOD but discrepancy of single scattering albedo and imaginary part of complex refractive index. One of the important reasons is due to the original assumption about the size distribution. It could be seen clearly in Fig. 5, the volume of coarse mode of SKYNET is larger than that of AERONET on average. The coarse mode particles have larger scattering ability than the fine mode particles. The SSA is defined by $\sigma_{\text {scattering }} /\left(\sigma_{\text {absorption }}+\sigma_{\text {scattering }}\right)$, which means the more coarse mode particles will cause more scattering, then the SSA retrieved from SKYNET would be larger than those of AERONET. 

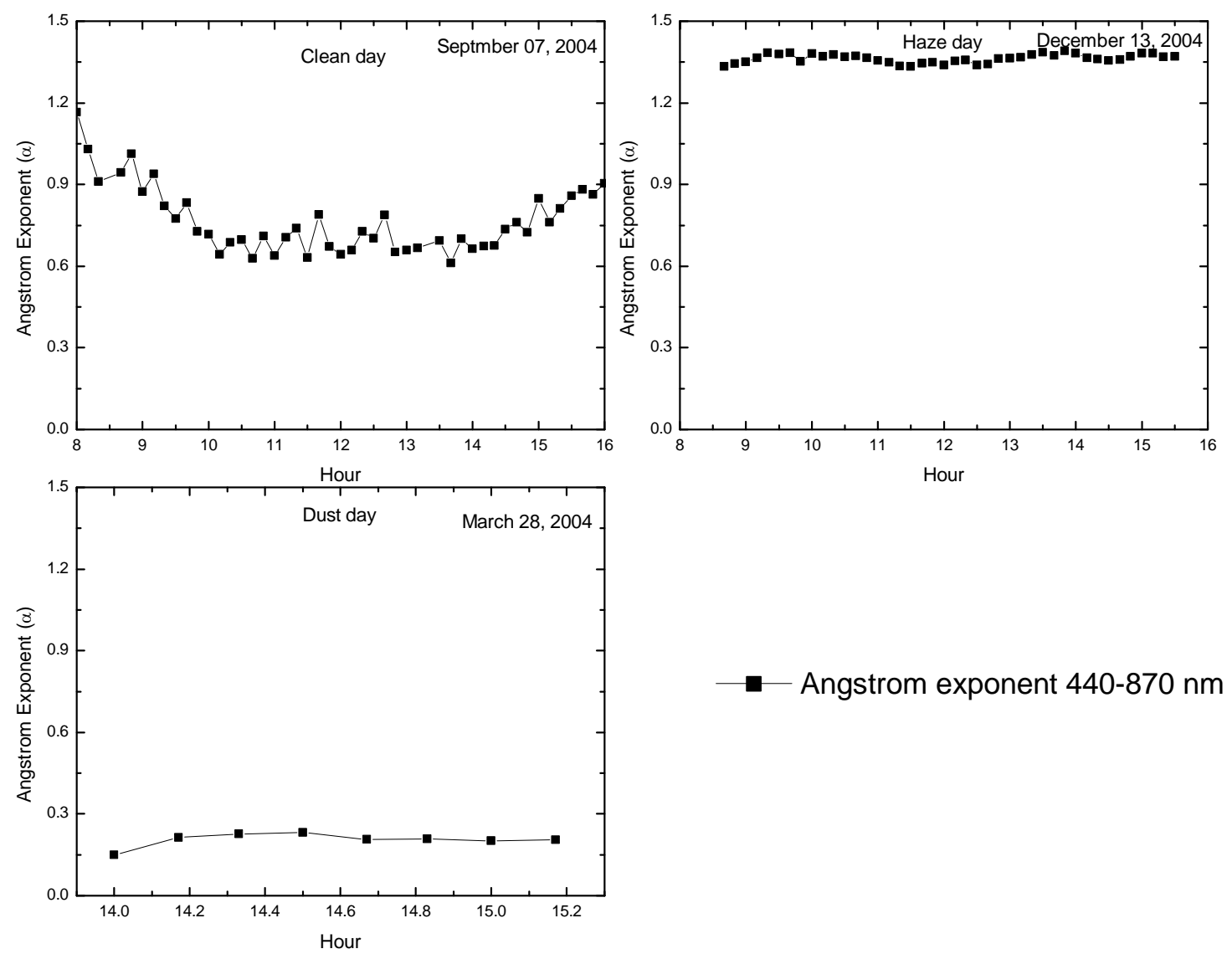

Fig. 11. Angstrom exponent $(\alpha)$ at $440-870 \mathrm{~nm}$ of skyradiometer under clean (top-left), haze (top-right) and dust (bottom-left) weather conditions over Beijing on 7 September, 13 December, and 28 March in 2004.

The imaginary parts of complex refractive index from the PREDE skyradiometer at all wavelengths are systematically lower than those by CIMEL sunphotometer. This could also be explained referring to Fig. 5. One can see the fine mode particles' proportion against the whole mode (from $0.01 \mu \mathrm{m}$ to $15 \mu \mathrm{m}$ ) of AERONET is larger than that of SKYNET. The refractive exponent consists of the real part and the imaginary part. The imaginary part reflects the absorption ability of aerosol particles. The volume of fine mode particles retrieved from AERONET is larger than that from SKYNET in most cases, which means the AERONET retrieved particles would have more absorption comparing to the SKYNET ones. This would probably cause larger imaginary part of complex refractive index for AERONET than SKYNET in Fig. 6.

3.2 Aerosol optical properties under clean, haze and dusty days

AQUA- MODIS (Moderate Resolution Imaging Spectroradiometer) satellite images (http://modis.gsfc.nasa.gov/) were used to judge the background (clean), haze (polluted) and dusty days over Beijing. The satellite overpass time is 04:55 UTC on 7 September in 2003, 05:35 UTC on 13 December in 2003, and 04:20 UTC on 28 March in 2004, respectively. From Fig. 7, it can be seen clearly that there was no pollution and cloud over Beijing on 7 September 2004 but with a heavy pollution on 13 December 2004 and sand-dust storm on 28 March 2004. To assure that no cloud was present during the whole day, pyranometer measurement data were used to check the atmospheric status on these two days. Figure 8 presents the variation of global irradiance during the whole day on 7 September and 13 December 2004. One can see that the global solar irradiance varies very smoothly, so that we can make sure that there are not any effects of cloud on these two days. However, it was a pity that there is no pyranometer measurement on 28 March.

Figure 9 presents the 5-min averages of $\mathrm{PM}_{10}$ concentrations on background, haze, and dusty days. From the figure one can see that the daily averaged mass concentrations are about 120,249 , and $378 \mu \mathrm{g} / \mathrm{m}^{3}$ on the three days. On the clean day, the $\mathrm{PM}_{10}$ concentration varies fluctuantly before 17:00 (beginning of the afternoon rush hour) with an average $83 \mu \mathrm{g} / \mathrm{m}^{3}$ and increases rapidly and varies more fluctuantly 

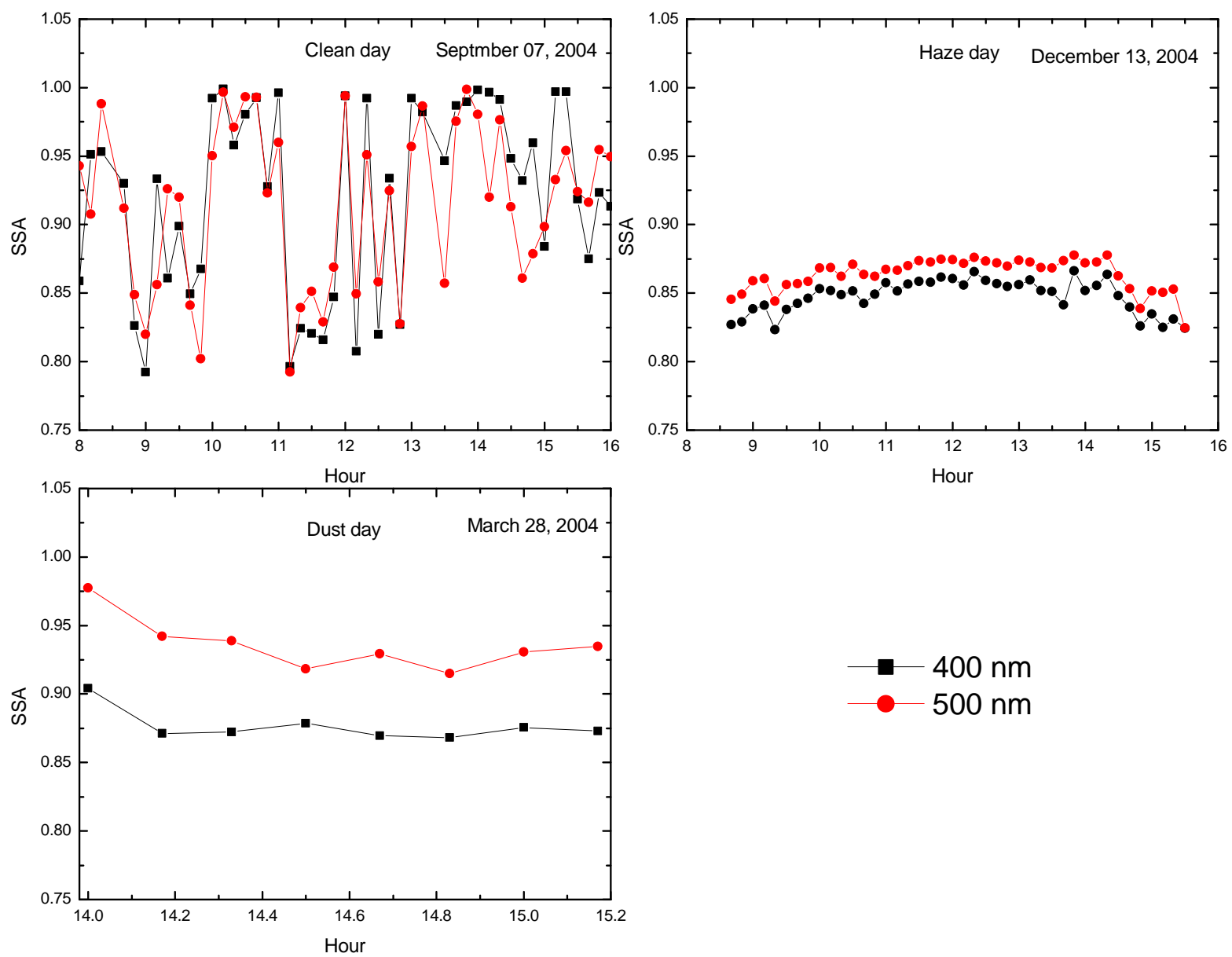

Fig. 12. Single scattering albedo $(\omega)$ at 400 and $500 \mathrm{~nm}$ retrieved from PREDE skyradiometer data under clean (top-left), haze (top-right) and dust (bottom-left) weather conditions over Beijing on 7 September, 13 December, and 28 March in 2004.

from 17:00 with an average $\sim 184 \mu \mathrm{g} / \mathrm{m}^{3}$. On the haze day, the mass concentration is as low as about $115 \mu \mathrm{g} / \mathrm{m}^{3}$ before 09:00 and increases to a higher value from 09:00 (beginning of the morning rush hour) and varies very stably on an average of $330 \mu \mathrm{g} / \mathrm{m}^{3}$. On the dusty day, the mass concentration is as high as about $411 \mu \mathrm{g} / \mathrm{m}^{3}$ before 19:00 and decreases to a lower value from 19:00 and varies fluctuantly on an average of $257 \mu \mathrm{g} / \mathrm{m}^{3}$.

Figure 10 shows the daily AOD variations from PREDE skyradiometer measurements on clean, haze and dusty days and daily averages of AOD retrieved from SKYNET and AERONET on haze and dusty days. There are 66, 42, and 8 effective measurements from SKYNET on these days, respectively. AOD on September 07 is very low over Beijing which could be regarded as the background AOD of Beijing. The daily averages of AOD on clean day are about $0.08 \pm 0.02,0.07 \pm 0.02,0.04 \pm 0.02,0.05 \pm 0.01,0.02 \pm 0.01$ at $400,500,670,870$, and $1020 \mathrm{~nm}$, respectively. AOD is very dependent on wavelengths during the haze day. The daily averaged AOD are about $1.20 \pm 0.10,0.96 \pm 0.09,0.67 \pm 0.06$,
$0.47 \pm 0.04,0.39 \pm 0.03$ at $400,500,670,870$, and $1020 \mathrm{~nm}$, respectively. However, the AOD on dusty day is more independent of wavelength than that on haze day. The daily averages of AOD on dust day are about $1.32 \pm 0.21,1.27 \pm 0.19$, $1.20 \pm 0.18,1.15 \pm 0.17,1.09 \pm 0.16$ at $400,500,670,870$, and $1020 \mathrm{~nm}$, respectively. The AOD values at $500 \mathrm{~nm}$ on haze day and on the dusty day are 13.5 and 18.0 times larger than that on clean day. These results are very similar to those from AERONET measurement over Beijing (Xia et al., 2005).

It is also found that the daily-averaged AOD values on haze day of SKYNET agree very well with the AERONET ones. But on the dusty day, the AOD retrieved by SKYNET is lower than by AERONET measurements, which is presumably because the assumption of spherical particles for SKYNET algorithm is wrong in this case.

The daily variation of Angstrom exponent $(\alpha)$ between 440 and $870 \mathrm{~nm}$ under three different weather conditions are shown in Fig. 11. It varies on the range of 0.61 to $1.24,1.33$ to 1.39 , and 0.15 to 0.23 on clean, haze and dust days, respectively. The averaged values of $\alpha$ are stably about $0.80,1.35$, 

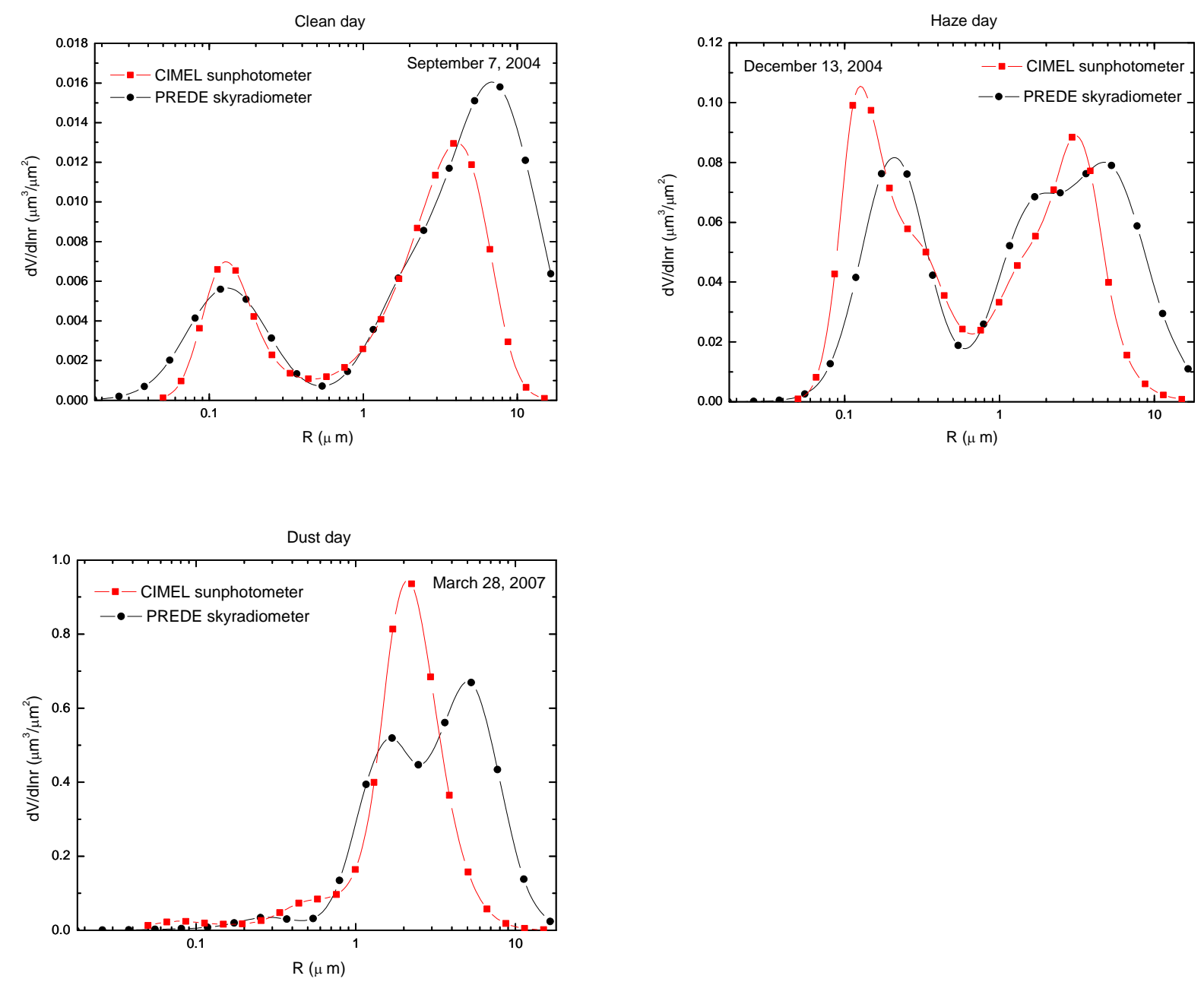

Fig. 13. Volume size distributions retrieved from PREDE skyradiometer and CIMEL sunphotometer data under clean (top-left), haze (topright) and dust (bottom-left) weather conditions over Beijing on 7 September, 13 December, and 28 March in 2004.

and 0.20 for the clean, haze and dusty days, which clearly reflects the contributions of fine particles on haze day and coarse ones on dusty day over Beijing.

The daily variation of single scattering albedo (SSA) at 400 and $500 \mathrm{~nm}$ under three different weather conditions are shown in Fig. 12. SSA on both haze day and dusty day varies smoothly; however, SSA on the clean day fluctuates a lot. This strong fluctuation of single scattering albedo is probably caused by the low AOD. The single scattering albedo, as well as other optical parameters, cannot be accurately determined at very low $(<0.40)$ AOD. The single scattering albedo values ranged from 0.99 to 0.78 at $400 \mathrm{~nm}$ and 0.99 to 0.71 at $500 \mathrm{~nm}$ for the clean day, 0.87 to 0.82 at $400 \mathrm{~nm}$ and 0.88 to 0.82 at $500 \mathrm{~nm}$ for the haze day, and 0.90 to 0.87 at $400 \mathrm{~nm}$ and 0.98 to 0.92 at $500 \mathrm{~nm}$ for the dusty day. The average values are about $0.90 \pm 0.08,0.85 \pm 0.01$, and $0.88 \pm 0.01$ at $400 \mathrm{~nm}$ and $0.88 \pm 0.08,0.86 \pm 0.01,0.93 \pm 0.02$ at $500 \mathrm{~nm}$ on the clean, haze and dusty days, respectively, which means the aerosol particles on haze day have more absorption abil- ity than those on dusty day. This can be concluded that the black carbon as well as sulfate and nitrate were the major components during haze day in Beijing. However,further experiment is needed to confirm this.

Volume size distributions retrieved by PREDE skyradiometer and CIMEL sunphotometer on the clean, haze, and dusty days are shown in Fig. 13. In general, the coarse modal volumes retrieved by PREDE skyradiometer are larger than those retrieved by CIMEL sunphotometer under all three distinct weather conditions. The size distributions on the clean day show classic bi-modal patterns for both PREDE skyradiometer and CIMEL sunphotometer. The effective radius of fine mode is about $0.09 \mu \mathrm{m}$ and coarse mode is about $3.48 \mu \mathrm{m}$ for PREDE skyradiometer. And the effective radii are about $0.13 \mu \mathrm{m}$ and $2.44 \mu \mathrm{m}$ for the fine and coarse modes of the CIMEL sunphotometer. The volume size distributions on haze and dusty days both show tri-modal patterns for PREDE skyradiometer. But bi-modal and single mode patterns were found on haze and dusty days for 

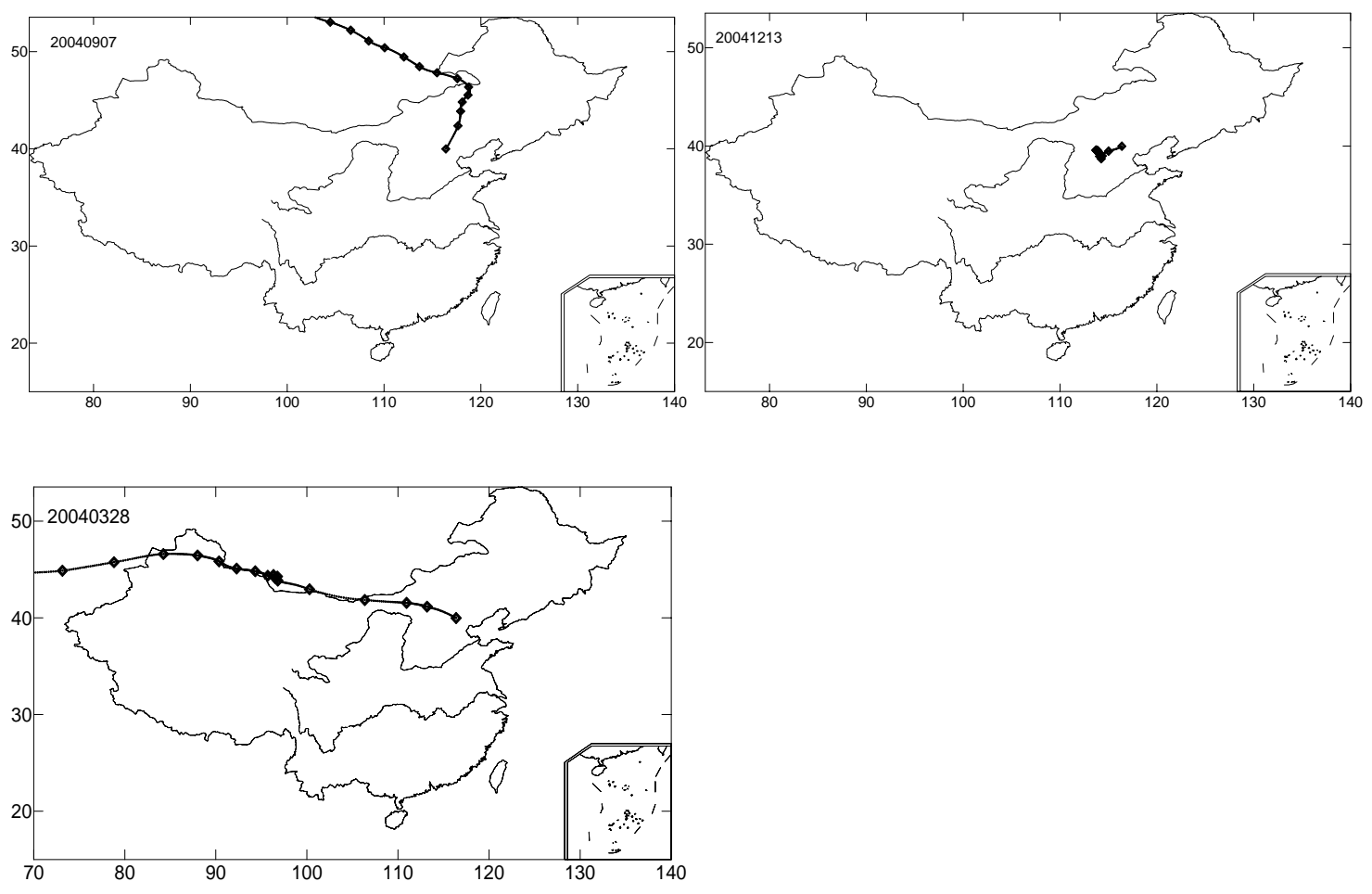

Fig. 14. The five day backtrajectory analyses under clean (top-left), haze (top-right) and dust (bottom-left) weather conditions over Beijing on 7 September, 13 December, and 28 March in 2004.

CIMEL sunphotometer. Although there are some differences between PREDE skyradiometer and CIMEL sunphotometer retrievals on the dusty day, the fine mode volumes with effective radii of $0.10 \mu \mathrm{m}$ for PREDE skyradiometer and $0.15 \mu \mathrm{m}$ for CIMEL sunphotometer are much smaller than the coarse mode $\left(\mathrm{r}_{\mathrm{eff}}=2.38 \mu \mathrm{m}\right.$ for PREDE skyradiometer; $\mathrm{r}_{\text {eff }}=1.83 \mu \mathrm{m}$ for CIMEL sunphotometer) which means the large particles contribute predominately to the aerosol optical properties. While on the haze day, the relative fine mode volume of aerosol particles is larger with respect to the total volume size distribution comparing to clean or dusty days which means the fine particles contribute larger under haze day than dust day to the aerosol optical properties. The effective radii of fine mode are about $0.13 \mu \mathrm{m}$ for PREDE skyradiometer and $0.16 \mu \mathrm{m}$ for CIMEL sunphotometer and the effective radii of coarse mode are about $2.21 \mu \mathrm{m}$ for PREDE skyradiometer and $2.03 \mu \mathrm{m}$ for CIMEL sunphotometer.

The 5-day backtrajectory analysis on $850 \mathrm{hPa}$ were calculated to examine the aerosol sources under different weather conditions by using the hybrid single-particle Lagrangian integrated trajectory (Hysplit) model of NOAA (Draxler et al., 2003). From Fig. 14, it is shown that there is a different transportation path for each atmospheric condition. The airmass on September 07 (clean day) was originally from Baikal Lake region of Siberia, and passed through east Mongolia southeastwardly and then crossed North China southeastwardly to Beijing. The regions where the airmass passed were of nei- ther pollution nor mineral dust particles. While on $13 \mathrm{De}-$ cember (haze day), the airmass was original from Shanxi Province, which is located west to Beijing with many industrial factories and coal-fired power plants with large anthropogenic aerosol emission there. It moved very slowly and passed through the west region of Hebei Province also with many industrial factories and steel plants. For the dusty days on 28 March 2004, the airmass was originally from Middle Asia and stayed over Gobi Desert for a long time then moved rapidly through the desert region of North China and arrived at Beijing.

\section{Conclusions}

The AOD measurements between SKYNET and AERONET measurements at Beijing are highly consistent at all of four normal wavelengths with less than $1.3 \%$ difference. Angstrom coefficients differ within 10-12\% between the two instruments. Single scattering albedo estimates retrieved by SKYRAD.PACK 4.2 inversion are $0.03(3.40 \%), 0.06$ $(7.33 \%)$, and $0.07(7.57 \%)$ larger than those provided by AERONET at 670, 870 and $1020 \mathrm{~nm}$. The SKYNET estimates at 400 and $500 \mathrm{~nm}$ are about $0.01(1.31 \%), 0.03$ (3.10\%) larger than AERONET single scattering albedo at $440 \mathrm{~nm}$ with high linear relative coefficient of 0.88 and 0.86 .

The volume distribution between SKYNET and AERONET are both with multi lognormal distribution 
patterns. On the contrary to the coarse mode, the fine mode volume concentration of SKYNET is less than that of AERONET. The size distribution retrieved from PREDE skyradiometer on the clean day shows classic bi-modal pattern with effective radii about $0.09 \mu \mathrm{m}$ for fine mode and $3.47 \mu \mathrm{m}$ for coarse mode. The volume size distributions retrieved from PREDE skyradiometer on haze and dusty days are both shown tri-modal patterns. The effective radii are about $0.13 \mu \mathrm{m}$ for fine mode and $2.21 \mu \mathrm{m}$ for coarse mode under haze weather condition and about $0.10 \mu \mathrm{m}$ for fine mode and $2.38 \mu \mathrm{m}$ for coarse mode under dust event weather condition. The difference is probably attributed to different measurement protocols and respective inversion algorithms.

The difference of real parts of refractive index obtained using the two algorithms does not exceed $2.6 \%$. The real parts of refractive index at wavelengths of 400 and $500 \mathrm{~nm}$ of PREDE skyradiometer are both lower than those of CIMEL sunphotometer at $440 \mathrm{~nm}$ but larger than those of CIMEL sunphotometer values at 670,870 , and $1020 \mathrm{~nm}$. The imaginary parts of refractive index of PREDE skyradiometer are less than those of CIMEL sunphotometer systematically.

The systematically larger single scattering albedo and smaller imaginary parts of refractive index of SKYNET retrievals comparing to the AERONET ones are probably due to the different original assumption about the volume size distribution.

It is found that under the haze and dusty weather conditions, the $\mathrm{PM}_{10}$ is about 2 to 3 times but the AOD is about 13.7 and 18.1 times higher than that under clean conditions. AOD on the dusty day is more independent of wavelength than that on haze days. The daily-averaged AOD values on haze day of SKYNET agree very well with the AERONET ones. Whereas the AOD retrieved by SKYNET is lower than that by AERONET on the dusty day, which is presumably because of the wrong assumption of spherical particles for SKYNET algorithm. The Angstrom exponents for the clean, haze and dusty days are about $0.80,1.35$, and 0.20 . The single scattering albedo values at $500 \mathrm{~nm}$ are $0.88,0.86,0.93$ on clean, haze and dusty days, respectively, which indicates aerosol particles on haze day have more absorption ability than mineral aerosols on the dusty day. The five-day backtrajectory analyses show that aerosol sources under clean, haze and dust weather conditions are originally from Baikal Lake of Siberia, regional industrial areas of western Beijing, Gobi and deserts of north China, respectively.

Although both the PREDE skyradiometer and CIMEL sunphotometer used in this study have been calibrated strictly according to the manufacturer standards, differences in the retrieved AOP still exist due to the differences in the retrieval schemes. Therefore, one should consider the impact of various retrieval schemes on the AOP when they are used in radiative forcing estimates, aerosol climate impact study and satellite calibrations.
Acknowledgements. This research was financially supported by grants from National Key Project of Basic Research (2006CB403705, 2006CB403701, and 2006CB403702). The authors would like to thank the three anonymous reviewers and the editor for their constructive suggestions and comments. The authors are grateful to OpenCLASTR project for using SKYRAD package in this research.

Edited by: T. Wagner

\section{References}

Ackerman, P. and Toon, O. B.: Absorption of visible radiation in atmosphere containing mixtures of absorbing and nonabsorbing particles, Appl. Optics, 20, 3661-3668, 1981.

Campanelli, M., Gobbi, G., Tomasi, C., and Nakajima, T.: Intercomparison between aerosol characteristics retrieved simultaneously with a Cimel and Prede sun-sky radiometers in Rome, Torvergata Aeronet site, ÓPTICA PURA Y APLICADA, 37, 3, 3159-3164, 2004a.

Campanelli, M., Nakajima, T., and Olivieri, B.: Determination of the Solar Calibration Constant for a Sun-Sky Radiometer: Proposal of an In-Situ Procedure, Appl. Optics, 43, 651-659, 2004b.

Charlson, R. J, Schwartz, S. E., Hales, J. M., Cess, D., and Coakley, J. A., and Hansen, J. E.: Climate forcing by anthropogenic aerosols, Science, 255, 423-430, 1992.

Che, H. Z., Shi, G. Y., Zhang, X. Y., Arimoto, R., Zhao, J. Q., Xu, L., Wang, B., and Chen, Z. H.: Analysis of 40 years of solar radiation data from China, 1961-2000, Geophys. Res. Lett., 32, L06803, doi:10.1029/2004GL022322, 2005.

Draxler, R. R. and Rolph, G. D.: HYSPLIT (HYbrid Single-Particle Lagrangian Integrated Trajectory) Model access via NOAA ARL READY Website (http://www.arl.noaa.gov/ready/hysplit4.html), NOAA Air Resources Laboratory, Silver Spring, MD, 2003.

Dubovik, O., Smirnov, A., Holben, B. N., King, M. D., Kaufman, Y. J., Eck, T. F., and Slutsker, I.: Accuracy assessments of aerosol optical properties retrieved from AERONET sun and sky radiance measurements, J. Geophys. Res., 105, 9791-9806, 2000a.

Dubovik, O. and King, M. D.: A flexible inversion algorithm for the retrieval of aerosol optical properties from Sun and sky radiance measurements, J. Geophys. Res., 105, 20 673-20 696, 2000 b.

Dubovik, O., Holben, B. N., Eck, T. F., Smirnov, A., Kaufman, Y. J., King, M. D., Tanre, D., and Slutsker, I.: Variability of absorption and optical properties of key aerosol types observed in worldwide locations, J. Atmos. Sci., 59, 590-608, 2002.

Dubovik, O., Sinyuk, A., Lapyonok, T., Holben, B. N., Mishchenko, M., Yang, P., Eck, T. F., Volten, H., Muñoz, O., Veihelmann, B., van der Zande, W. J., Leon, J., Sorokin, M., and Slutsker, I.: Application of spheroid models to account for aerosol particle nonsphericity in remote sensing of desert dust, J. Geophys. Res., 111, doi:10.1029/2005JD006619, 2006.

Eck, T. F., Holben, B. N., Dubovik, O., Smirnov, A., Goloub, P., Chen, H. B., Chatenet, B., Gomes, L., Zhang, X. Y., Tsay, S. C., Ji, Q., Giles, D., and Slutske, I.: Columnar aerosol optical properties at AERONET sites in central eastern Asia and aerosol transport to the tropical mid-Pacific, J. Geophys. Res., 110, D06202, doi:10.1029/2004JD005274, 2005. 
Eck, T. F., Holben, B. N., Reid, J. S., Dubovik, O., Smirnov, A., O'Neill, N. T., Slutsker, I., and Kinne, S.: Wavelength dependence of the optical depth of biomass burning, urban, and desert dust aerosols, J. Geophys. Res., 104, 31 333-31 349, 1999.

Hansen, J., Sato, M., and Ruedy, R.: Radiative forcing and climate response, J. Geophys. Res., 102, 6831-6864, 1997.

Hansen, J., Sato, M., Ruedy, R., Lacis, A., and Oinas, V.: Global warming in the twenty-first century: An alternative scenario, Proc. Natl. Acad. Sci. U. S. A., 97, 9875-9880, 2000.

Holben, B. N., Eck, T. F., Slutsker, I., et al.: AERONET - A federated instrument network and data archive for aerosol characterization, Remote Sens. Environ., 66, 1-16, 1998.

Holben, B. N., Tanré, D., Smirnov, A., et al.: An emerging ground-based aerosol climatology: Aerosol optical depth from AERONET, J. Geophys. Res., 106, 12 067-12 097, 2001.

Intergovernmental Panel on Climate Change (IPCC): Climate Change 2001: in: The Scientific Basis, edited by: Houghton, J. T., Ding, Y., Griggs, D. I., et al., 896 pp., Cambridge Univ. Press, New York, 2001.

Kim, D. H., Sohn, B. J., Nakajima, T., Takamura, T., Choi, B. C., and Yoon, S. C.: Aerosol optical properties over east Asia determined from ground-based sky radiation measurements, J. Geophys. Res., 109, D02209, doi:10.1029/2003JD003387, 2004.

Menon, S., Hansen, J. E., Nazarenko, L., and Luo, Y. F.: Climate effects of black carbon aerosols in China and India, Science 297, 2249-2252, 2002.

Nakajima, T., Sekiguchi, M., Takemura, T., et al.: Significance of direct and indirect radiative forcings of aerosols in the East China Sea region, J. Geophys. Res., 108(D23), 8658, doi:10.1029/2002JD003261, 2003.

Nakajima, T., Tonna, G., Rao, R., and Holben, B. N.: Use of sky brightness measurements from ground for remote sensing of particulate polydispersions, Appl. Optics, 35, 2672-2686, 1996.

O'Neill, N. T., Ignatov, A., Holben, B. N., and Eck, T. F.: The lognormal distribution as a reference for reporting aerosol optical depth statistics; Empirical tests using multi-year, multi-site AERONET sunphotometer data, J. Geophys. Lett., 27, 20, 33333336, 2000.
Ramanathan, V., Crutzen, P. J., Lelieveld, J., et al.: The Indian Ocean Experiment: An integrated analysis of the climate forcing and effects of the great Indo-Asian haze, J. Geophys. Res., 106, 28, 371-398, 2001.

Sano, I., Mukai, S., Yamano, M., Takamura, T., Nakajima, T., and Holben, B. N.: Calibration and validation of retrieved aerosol properties based on Aeronet and Skynet, Adv. Space Res., 32, 11, 2159-2164, 2003.

Smirnov, A., Holben, B. N., Eck, T. F., Dubovik, O., and Slutsker, I.: Cloud screening and quality control algorithms for the AERONET database, Remote. Sens. Environ., 73, 337-349, 2000.

Smirnov, A., Holben, B. N., Eck, T. F., Slutsker, I., Chatenet, B., and Pinker, R. T.: Diurnal variability of aerosol optical depth observed at AERONET (Aerosol Robotic Network) sites, Geophys. Res. Lett., 29, 23, 2115, doi:10.1029/2002GL016305, 2002.

Stanhill, G. and Cohen, S.: Global dimming: a review of the evidence for a widespread and significant reduction in global radiation with discussion of its probable causes and possible agricultural consequences, Agr. Forest Meteorol., 107, 255-278, 2001.

Takemura, T., Nakajima, T., Dubovik, O., Holben, B. N., and Kinne, S.: Single scattering albedo and radiative forcing of various aerosol species with a global three-dimensional model, J. Climate, 15, 333-352, 2002.

Uchiyama, A., Yamazaki, A., Togawa, H., and Asano, J.: Characteristics of Aeolian dust observed by sky-radiometer in the Intensive Observation Period 1 (IOP1), J. Meteor. Soc. Japan, 83A, 291305, 2005.

Xia, X. A., Chen, H. B., Wang, P. C., Zong, X. M., Qiu, J. H., and Goloub, P.: Aerosol properties and their spatial and temporal variations over north China in spring 2001, Tellus, 57B, 28-39, 2005. 